\title{
Development and growth in larval and juvenile Hyas coarctatus (Decapoda, Majidae) reared in the laboratory*
}

\author{
K. Anger \\ Biologische Anstalt Helgoland, Meeresstation, D-2192 Helgoland, Federal Republic of Germany
}

\begin{abstract}
Larvae of the spider crab Hyas coarctatus Leach were reared in the laboratory. Duration of development in the larval and early juvenile stages was studied in relation to temperature, and compared to previous findings in a closely related species, $H$. araneus. Mortality in $H$. coarctatus was higher at extreme $\left(18\right.$ and $\left.6^{\circ} \mathrm{C}\right)$ than at intermediate $\left(9\right.$ to $\left.15^{\circ} \mathrm{C}\right)$ temperatures. The laboratory-derived results were used to estimate the duration of development from hatching to the third crab stage in the field. Settling and metamorphosis was predicted to occur mainly during June. Biomass, measured as early postmoult dry weight, carbon, nitrogen, and hydrogen, increased exponentially during larval development from hatching to metamorphosis. Juvenile growth (increase in carapace length) was also exponential, and was maximum at $9^{\circ} \mathrm{C}$, and minimum at 18 and $6^{\circ} \mathrm{C}$. Growth rates observed in the laboratory would suggest that: (1) in the field $H$. coarctatus probably reaches sexual maturity and its final body size during the second year of postlarval life $e_{i}(2)$ first offspring can hatch 2 yr after hatching of the mother generation; ( 3 ) freshly hatched $H$. coarctatus larvae are smaller and contain much less biomass than those of $H$. araneus, but because of higher growth rates they catch up with $H$. araneus, and juvenile crabs of these species are of equal size in the same instar. However, growth and moulting cease earlier (after fewer moults) in $H$. coarctatus, so that its final size is much smaller than $H$. araneus.
\end{abstract}

\section{INTRODUCTION}

The closely related spider crab species Hyas coarctatus and $H$. araneus co-exist over a wide geographic range along the European and American coasts of the North Atlantic Ocean (Christiansen, 1969, 1973, 1982). Both are commonly found over a wide depth range in various types of subtidal habitats (Christiansen, 1969; Ingle, 1980). They appear to have a very similar reproductive biology, and their larvae hatch in the same period in late winter and in spring (for recent review of literature see Ingle, 1980). In addition, the morphology of larval and early juvenile stages of the 2 species is very similar (Christiansen, 1973).

A number of laboratory investigations have been carried out on larval development and growth in Hyas araneus (for recent review see Anger, 1984a), but apart from the observations by Christiansen (1973), very little is known about $H$. coarctatus. This paper represents

\footnotetext{
- Supported by Deutsche Forschungsgemeinschaft (An - 145/ $1-1)$
}

the first detailed study on rates of larval and postlarval growth and development of $H$. coarctatus, and thus enables a comparison to be made between these 2 species of majid crabs.

\section{MATERIALS AND METHODS}

Obtaining and handling of larvae and juveniles. Ovigerous females of Hyas coarctatus were dredged from ca. 20 to $50 \mathrm{~m}$ depth near the island of Helgoland (German Bight, North Sea) and maintained for several weeks in the laboratory. Females collected in winter were kept at constant $6^{\circ} \mathrm{C}$, those in summer at $12^{\circ} \mathrm{C}$. Larvae hatched on Apr 3,1982, Aug 12, 1982, and on Jan 24, 1983 from 3 different females. They were collected and reared individually over a range of temperatures from 6 to $18^{\circ} \mathrm{C}$ (Table 1) using methods previously described for $H$. araneus (Anger and Dawirs, 1981; Kunisch and Anger, 1984). The latter paper also described the techniques used for rearing juvenile crabs. H. coarctatus hatched in Jan, 1983, were maintained in the laboratory through 1 yr 


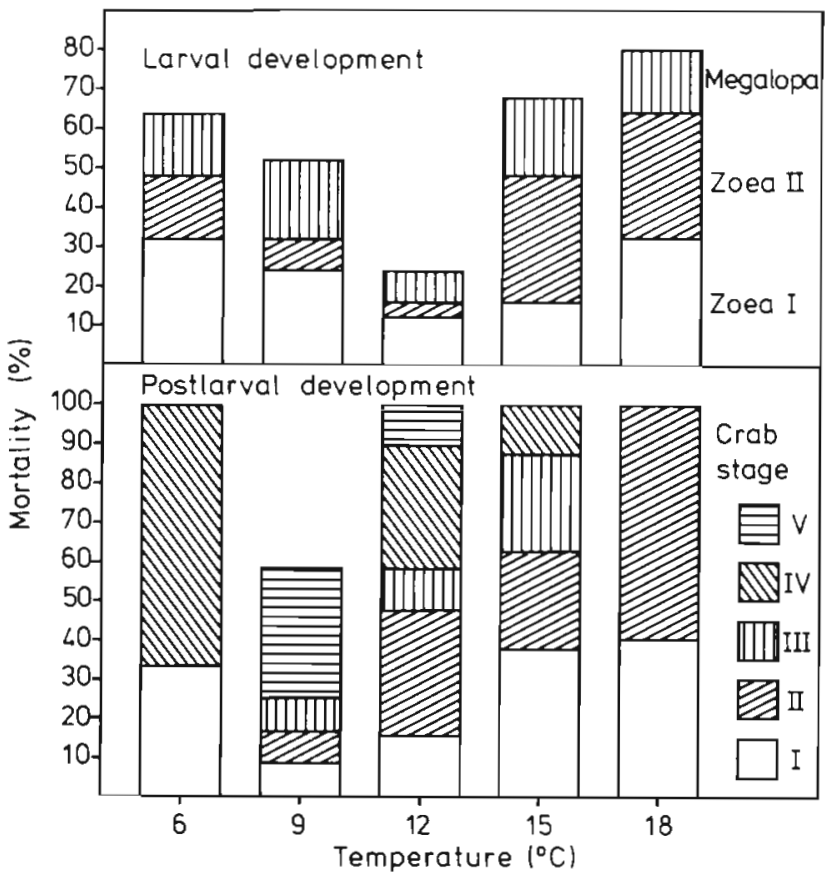

Fig. 1. Hyas coarctatus. Mortality (\%) in larval and postlarval development in relation to rearing temperature $\left({ }^{\circ} \mathrm{C}\right)$. Percentage figures related to the initial number of larvae $(n=25)$ in each experiment, or to the number of individuals surviving metamorphosis, respectively

Determination of growth rates. Growth (increase in biomass or size) was determined as described by Anger (1984b). In freshly hatched or moulted larvae, and in 1 freshly metamorphosed juvenile, dry weight (DW), total particulate carbon (C), nitrogen (N), and hydrogen (H) were measured. Energy content was estimated from carbon (Salonen et al., 1976). Carapace length (defined as distance from the tip of the rostrum to the rear margin of the carapace) of juvenile crabs and exuviae were measured to the nearest $0.05 \mathrm{~mm}$ by means of a stereo-microscope and an eyepiece mic- rometer. Statistical procedures employed were the same as those referred to by Anger and Dawirs (1981) and Anger (1983).

\section{RESULTS}

\section{Rates of mortality and development in relation to temperature}

Table 1 shows mortality and duration of development from hatching through metamorphosis in 11 rearing experiments. The larvae hatched in August experienced an extremely high mortality, which increased with increasing temperature. The few larvae which survived from this hatch to metamorphosis were reared at $6^{\circ} \mathrm{C}$. Fastest mortality was observed at $18^{\circ} \mathrm{C}$. This also applied to the January hatch, which was generally much more viable. In this hatch, survival was highest at $12^{\circ} \mathrm{C}$, and decreased toward the extreme temperatures, 6 and $18^{\circ} \mathrm{C}$ (Fig. 1).

Due to the relatively high percentage surviving to metamorphosis, mortality in this hatch could be further followed through the first juvenile stages. Fig. 1 suggests that there may be a shift in temperature tolerance after reaching the first crab stage. Mortality was now lowest at $9^{\circ} \mathrm{C}$, followed by $12^{\circ} \mathrm{C}$. At $18^{\circ} \mathrm{C}$ only the second crab stage was reached. The few survivors remained in this instar for up to $9 \mathrm{wk}$ without moulting, and then died. At 15 and $6^{\circ} \mathrm{C}$ the crabs ceased moulting in the fourth, and at $12^{\circ} \mathrm{C}$ in the fifth instar. When the experiment was terminated (Jan 1984) survivors at $9^{\circ} \mathrm{C}$ had already reached the crab VII instar.

Rate of larval development in relation to temperature showed some variation from hatch to hatch (Table 1). Since there was almost complete mortality in the megalopa stage of the August hatch, comparison with the January hatch is possible only in the zoeal stages. Zoea I development was consistently slower in

Table 1. Hyas coarctatus. Duration of development (days) and cumulative mortality $\left(\mathrm{M}_{i} \%\right)$ in larvae from different hatches reared at different constant temperatures $\left(\mathrm{T} ;{ }^{\circ} \mathrm{C}\right)$. Arithmetic mean \pm standard deviation

\begin{tabular}{|c|c|c|c|c|c|c|c|c|}
\hline \multirow[b]{2}{*}{ Hatch } & \multirow[b]{2}{*}{$\mathrm{T}\left({ }^{\circ} \mathrm{C}\right)$} & \multicolumn{2}{|c|}{ Zoea I } & \multicolumn{2}{|c|}{ Zoea II } & \multicolumn{2}{|c|}{ Megalopa } & \multirow{2}{*}{$\begin{array}{c}\Sigma \text { Larval development } \\
\text { Days }\end{array}$} \\
\hline & & Days & $M(\%)$ & Days & $M(\%)$ & Days & $M(\%)$ & \\
\hline 03 Apr, 1982 & 12 & $13.7 \pm 0.7$ & 0 & $14.2 \pm 0.8$ & 0 & $26.3 \pm 1.5$ & 88 & $55.3 \pm 2.1$ \\
\hline \multirow[t]{5}{*}{12 Aug, 1982} & 6 & $35.7 \pm 1.4$ & 0 & $36.5 \pm 1.5$ & 4 & $55.3 \pm 6.7$ & 88 & $126.3 \pm 6.4$ \\
\hline & 9 & $20.6 \pm 1.1$ & 48 & $21.6 \pm 1.0$ & 52 & - & 100 & - \\
\hline & 12 & $14.9 \pm 0.7$ & 72 & $13.5 \pm 0.6$ & 84 & - & 100 & - \\
\hline & 15 & $10.5 \pm 0.5$ & 48 & $10.2 \pm 0.6$ & 52 & - & 100 & - \\
\hline & 18 & $9.3 \pm 0.5$ & 72 & 8 & 96 & - & 100 & - \\
\hline \multirow[t]{5}{*}{24 Jan, 1983} & 6 & $30.4 \pm 1.5$ & 32 & $35.5 \pm 1.1$ & 48 & $42.8 \pm 1.6$ & 64 & $108.7 \pm 1.9$ \\
\hline & 9 & $19.0 \pm 1.0$ & 24 & $21.0 \pm 0.7$ & 32 & $28.0 \pm 1.1$ & 52 & $68.0 \pm 2.2$ \\
\hline & 12 & $12.4 \pm 0.5$ & 12 & $13.5 \pm 0.7$ & 16 & $20.4 \pm 1.4$ & 24 & $46.3 \pm 1.9$ \\
\hline & 15 & $10.0 \pm 0.6$ & 16 & $10.3 \pm 0.5$ & 48 & $16.4 \pm 0.7$ & 68 & $36.5 \pm 0.9$ \\
\hline & 18 & $8.4 \pm 0.6$ & 32 & $8.1 \pm 0.6$ & 64 & $13.4 \pm 1.5$ & 80 & $30.0 \pm 1.2$ \\
\hline
\end{tabular}


the August hatch than in larvae hatched in January. In the zoea II, the duration of development was almost equal in larvae from both hatches (Table 1). The duration of development of the megalopa stage in the few survivors of the August hatch which reached metamorphosis (at $6^{\circ} \mathrm{C}$ ) was strongly delayed and highly variable compared with larvae hatched in January. The latter also developed faster than the larvae originating from the April hatch.

Duration of development $(D)$ in single larval stages and from hatching to metamorphosis, in relation to temperature $(T)$ can be expressed as a power function:
$\mathrm{D}=\mathrm{a} \cdot \mathrm{T}^{-\mathrm{m}}$ or linearized $\ln \mathrm{D}=\ln \mathrm{a}-\mathrm{m} \cdot \ln \mathrm{T}(1)$

Fig. 2 shows the regression curves and equations for complete larval development in the January hatch (including mean values, standard deviations, and ranges), and for zoeal development in the August hatch (for sake of clarity without measured values; cf. Table 1). The latter showed higher a values reflecting longer development, particularly at low temperatures, and somewhat steeper slopes $(m)$ than the former. These differences between the 2 hatches were more pronounced in the first than in the second zoeal stage (Fig. 1; Table 1).
Fig. 2. Hyas coarctatus. Duration of larval development $(\mathrm{D}=$ days) in relation to temperature $\left(T,{ }^{\circ} \mathrm{C}\right) . \mathbf{r}=$ correlation coefficient, $\mathrm{n}=$ number of observations; $\mathrm{a}_{1} \mathrm{~b}=$ different hatches (see Table 1). Hatch (a): mean values $\pm \mathrm{SD}$ (bars) and ranges (thin lines) of $D_{i}$ hatch (b): only fitted curves given (values in Table 1)

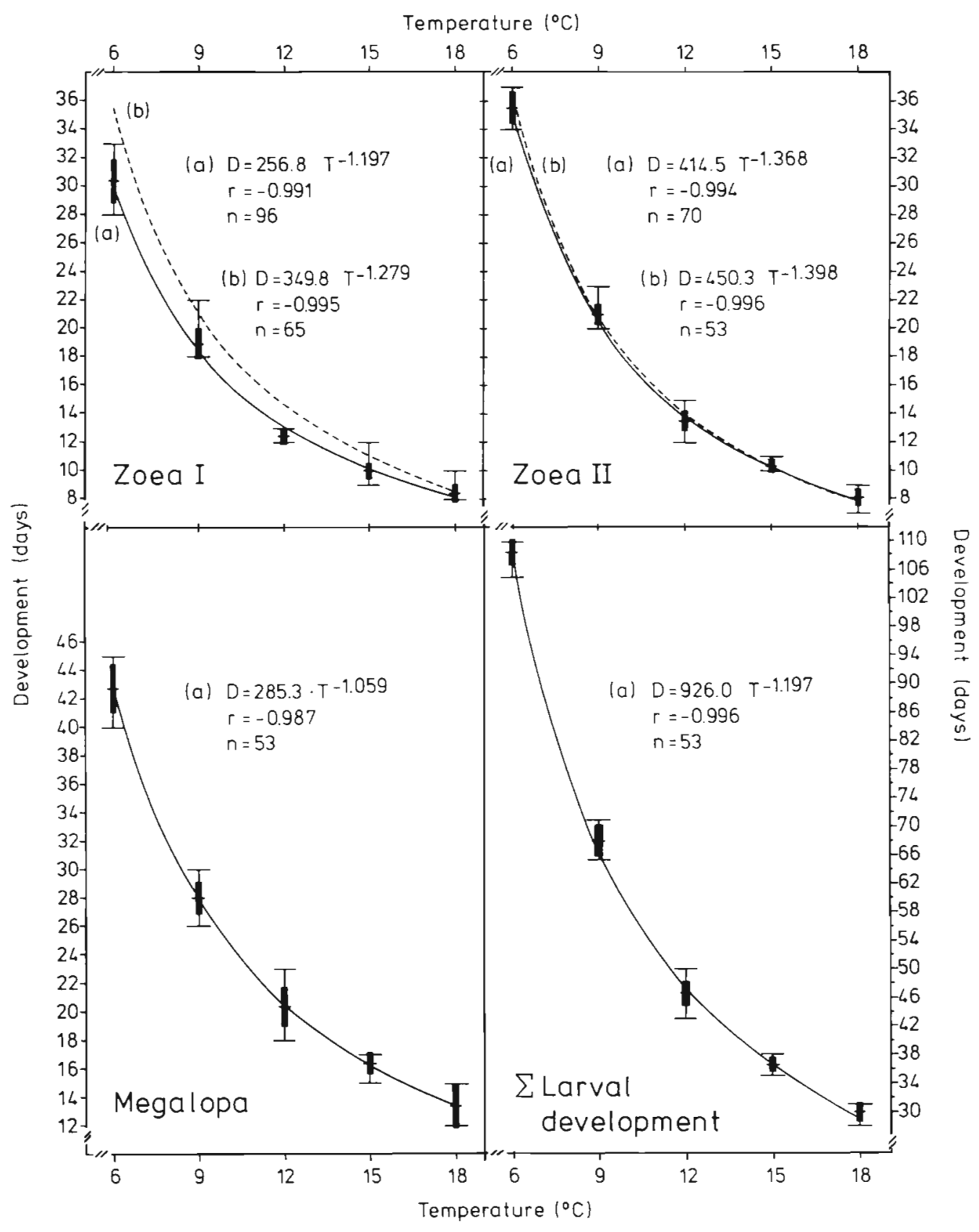


Table 2. Hyas coarctatus (H. c.) and $H$. araneus (H. a.). Parameters of the equation $\mathrm{D}=\mathrm{a} \cdot \mathrm{T}^{-\mathrm{m}} ; \mathrm{D}=$ duration of development (days); $\mathrm{T}=$ temperature $\left({ }^{\circ} \mathrm{C}\right) ; \mathbf{m}=$ regression coefficient of the linearized equation $(\ln \mathrm{D}=\ln \mathrm{a}-\mathrm{m} \cdot \ln \mathrm{T}) ; \mathrm{a}=$ intercept ( $\ln \mathrm{T}=0$; i.e. $\mathrm{a}=$ theoretical $\mathrm{D}$ at $1^{\circ} \mathrm{C}$ ); $\mathbf{r}=$ correlation coefficient. Values for H. a. from Anger (1983)

\begin{tabular}{|lccccccc}
\hline Stage & H. c. & a & H. a. & H.c. & H.a. & H.c. & H.a. \\
\hline Zoea I & 256.8 & 134.9 & 1.197 & 0.962 & -0.991 & -0.992 \\
Zoea II & 414.5 & 171.9 & 1.368 & 0.974 & -0.994 & -0.992 \\
$\begin{array}{l}\text { Megalopa } \\
\text { Larval }\end{array}$ & 285.3 & 139.4 & 1.059 & 0.646 & -0.987 & -0.930 \\
development & 926.0 & 543.2 & 1.197 & 0.922 & -0.996 & -0.991 \\
\hline
\end{tabular}

The parameters of the equations describing the relation between duration of development and temperature are compiled in Table 2 for Hyas coarctatus (Jan hatch) and $H$. araneus (from Anger, 1983). It is obvious that $H$. coarctatus develops much more slowly than $H$. araneus at low temperatures (higher a values), but that its rate of development increases with increasing temperature faster than in $H$. araneus (higher $m$ values). As a consequence, the regression curves (or lines, if plotted in a log-log scale) of the 2 species cross, and $H$. coarctatus develops faster than $H$. araneus at the highest temperatures within the range tolerated. The 2 species have the following characteristics in common: the slope $(m)$ is highest in the zoea $I$, lowest in the

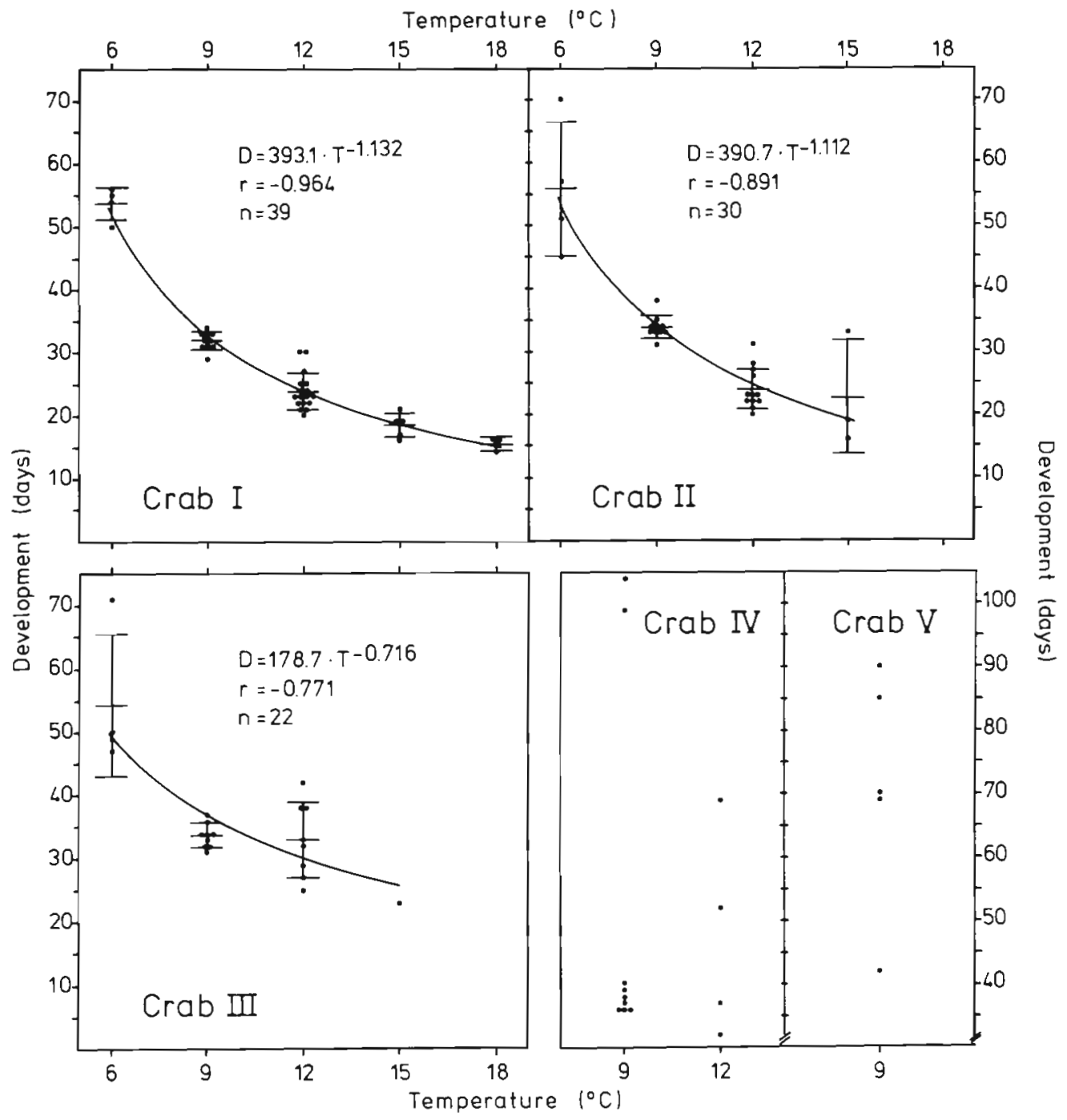

Fig. 3. Hyas coarctatus Duration of postlarval development in relation to temperature. Symbols as in Fig. 2 
Fig. 4. Hyas coarctatus. Simulated larval and early postlarval development in the field near Helgoland, in relation to the time of hatching. Average water temperature (smoothed curve) after values by Weigel (1978), from Anger, 1983

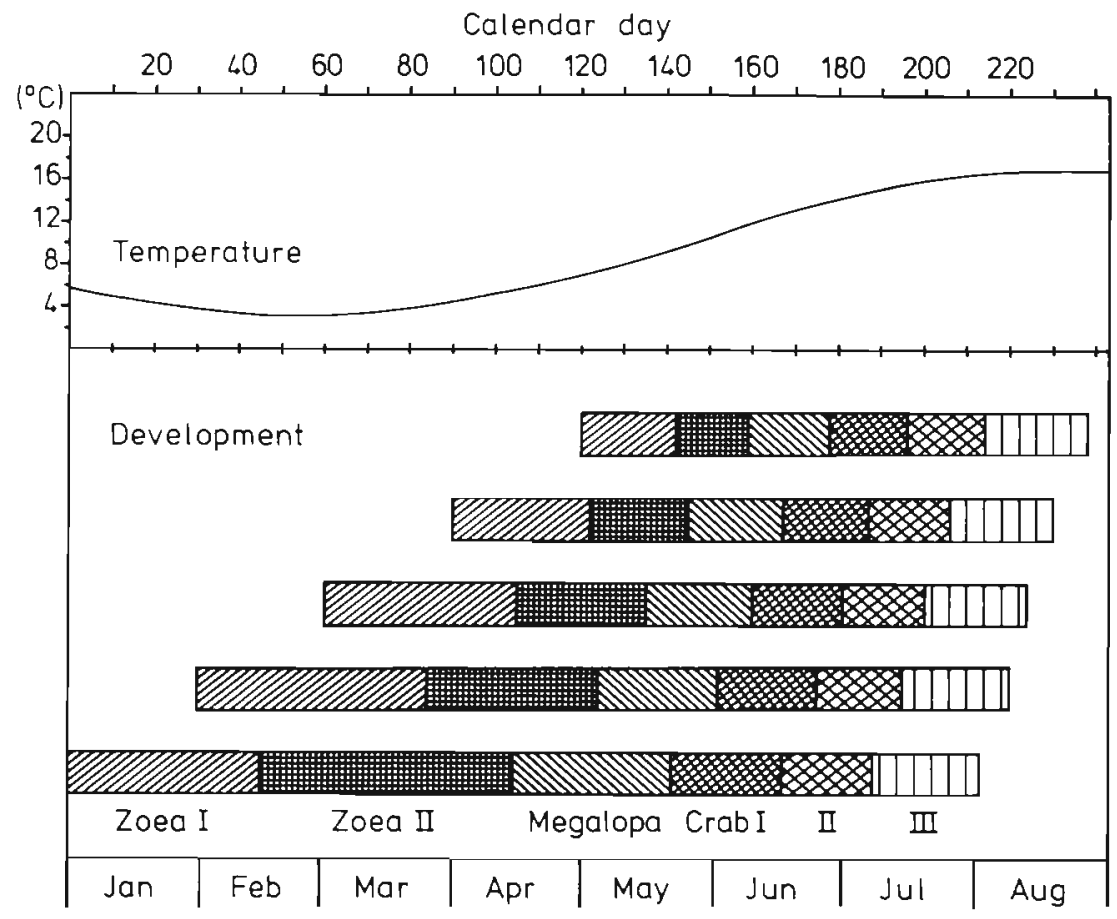

megalopa, and intermediate in the first zoeal stage (Table 2). It is also obvious that the fit (r) of the observed and predicted duration of development is poorest in the megalopa in both species. This is due to high variation in the ultimate larval stage.

Development duration of juvenile crabs (Stages I to $\mathrm{V})$ is shown in Fig. 3. Due to decreasing individual numbers and increasing variability during development, regression equations can only be given for the first 3 instars. The decreasing slopes $(\mathrm{m})$ and correlation coefficients $(r)$ suggest that the degree of dependence of development rate upon the temperature decreases with each successive instar in growing crabs.

The regression equations given in Fig. 2 and 3 (hatch from Jan) were also included in a simulation model developed by Anger (1983) for Hyas araneus, in order to estimate approximate development in the field. Fig. 4 shows average water temperature near Helgoland (smoothed curve, values from Weigel, 1978; after Anger, 1983) and predicted development from hatching (assumed to take place mainly from Jan through Apr) through the third crab stage. Increasing water temperatures in spring result in a progressive reduc-

Table 3. Hyas coarctatus. Individual dry weight (DW), carbon (C), nitrogen (N), hydrogen (H), C/N and C/H ratios, and energy (J) in larvae and one juvenile (all freshly hatched or moulted, respectively); arithmetic mean \pm standard deviation; $A, B=$ different hatches; $\mathrm{n}=$ number of replicate analyses; $\mathrm{N}=$ total number of individuals analysed

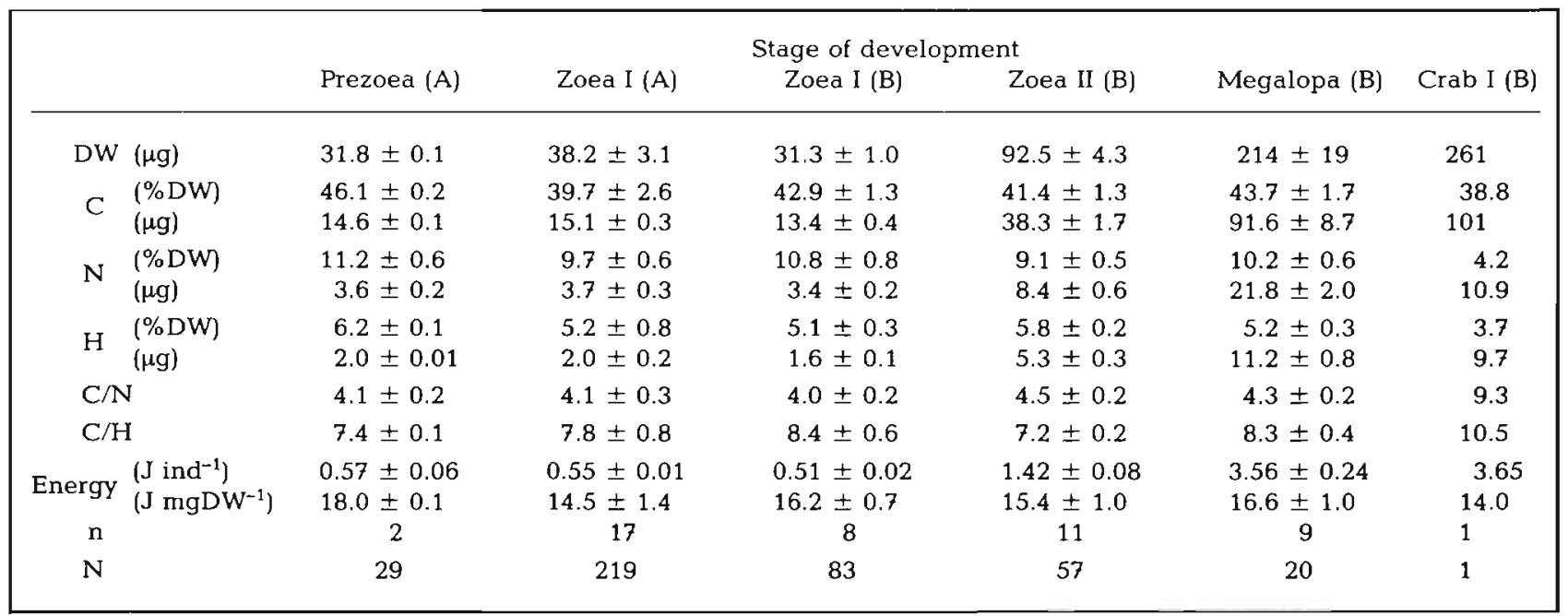


tion in the duration of Iarval development during this period. The predicted period of metamorphosis ranges from late May to late June, and the fourth juvenile instar should be reached during the month of August, regardless of- the time of hatching (Fig. 4). Further growth of juvenile crabs will be discussed below.

\section{Larval growth}

Changes in biomass and energy during larval development from hatching to metamorphosis are presented in Table 3 . In the prezoeal and crab I stages only a few occasional analyses were made. Comparison is possible between freshly hatched zoea I larvae originating from two different hatches (both from Apr, 1982), and between initial values of all larval stages (from the same hatch).

Freshly hatched zoea I larvae revealed a high degree of variation, particularly in dry weight and carbon. The increase in biomass and energy of early postmoult larvae follows an exponential pattern:

$$
\ln y=b+m \cdot S \text { (linearized form), }
$$

where y $=$ any measurement of biomass $(\mu \mathrm{g})$ or energy (J) per individual; $S=$ instar number ( $1=$ zoea Ii $2=$ zoea II $3=$ megalopa); $b=$ intercept; $m=$ slope (regression coefficient) of the above regression line.

The parameters of these equations describing larval growth are compiled in Table 4 for Hyas coarctatus (hatch B; data from Table 3 ) and $H$. araneus (data from Anger, 1984b). Consistently lower $b$ values in $H$. coarctatus reflect the lower initial biomass in this species compared with $H$. araneus. However, the slopes of the regression lines are higher in $H$. coarctatus, whatever measure of biomass is considered (Table 4). As a consequence, this species has almost caught up with $H$. araneus by the early postmoult megalopa.

Table 4. Hyas coarctatus (H.c.) and $H$ araneus (H. a.). Parameters of the growth equation $\ln y=b+m \quad S$; $y=d r y$ weight (DW), carbon (C), nitrogen $(N)$, hydrogen $(H)$ (all in $\mu \mathrm{g})$, or energy $(\mathrm{J})$, in early postmoult larvae; $\mathrm{S}=$ larval stage ( $1=$ zoea I, $2=$ zoea II, $3=$ megalopa $) ; \mathbf{b}=$ intercept; $\mathbf{m}=$ regression coefficient; $\mathbf{r}=$ correlation coefficient. Parameters for H. a. calculated from data in Anger (1984b)

\begin{tabular}{|lcccccc|}
\hline & \multicolumn{2}{c}{ b } & \multicolumn{2}{c}{ m } & \multicolumn{2}{c|}{} \\
y & H.c. & H. a. & H.c. & H. a. & H.c. & H. a. \\
\hline DW & 2.523 & 3.367 & 0.961 & 0.715 & 0.9973 & 0.9999 \\
C & 1.664 & 2.312 & 0.961 & 0.819 & 0.9986 & 0.9953 \\
N & 0.286 & 0.881 & 0.929 & 0.816 & 0.9999 & 0.9998 \\
H & -0.428 & 0.305 & 0.973 & 0.855 & 0.9912 & 0.9922 \\
J & -1.627 & -1.060 & 0.972 & 0.868 & 0.9995 & 0.9905 \\
\end{tabular}

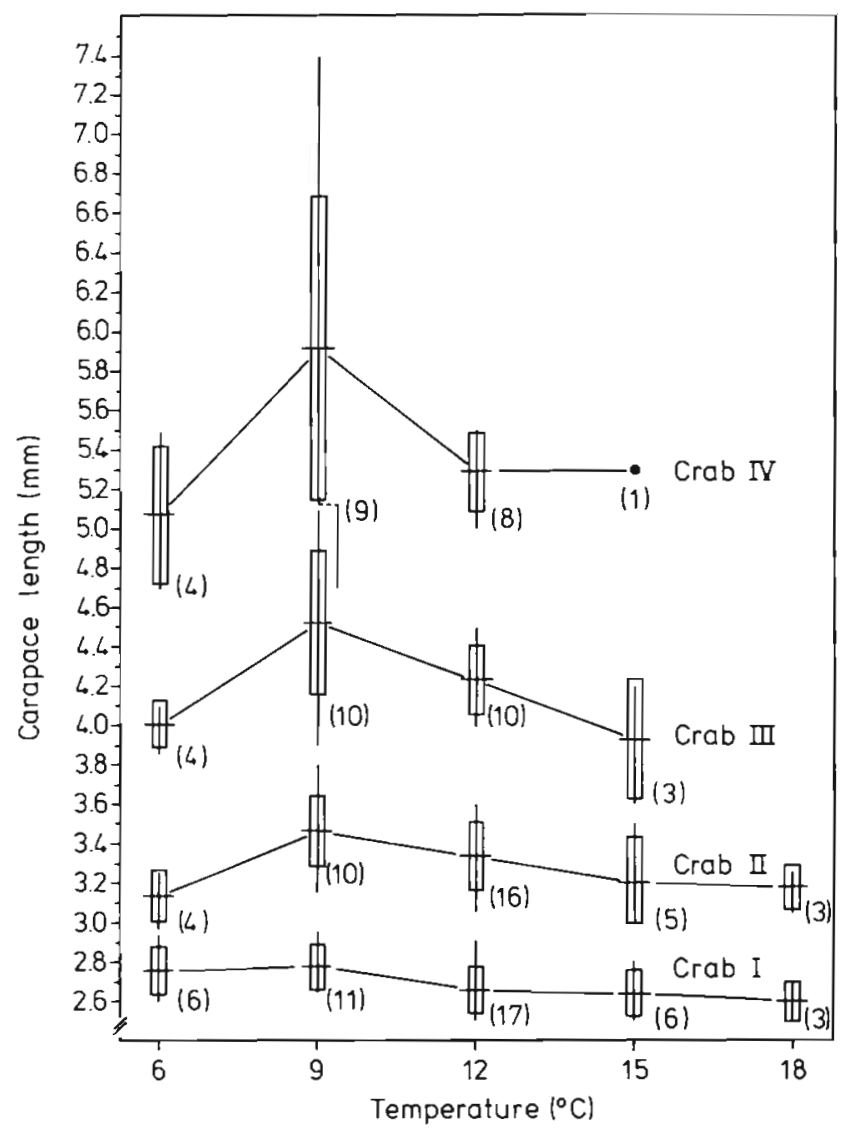

Fig. 5. Hyas coarctatus. Juvenile growth (carapace length: arithmetic mean \pm standard deviation; range) at different temperatures. Numbers in parentheses: number of observations

\section{Juvenile growth}

Growth of juvenile crabs was not measured as increase in biomass but in size. Carapace length of Stage I to IV crabs reared at different constant temperatures is shown in Fig. 5. Largest juveniles (first instar) were obtained from larvae reared at 9 and $6^{\circ} \mathrm{C}$, smallest crabs occurred at $18^{\circ} \mathrm{C}$. The differences between experimental groups increased during juvenile development, with highest growth rates in the group reared at $9^{\circ} \mathrm{C}$ and lowest rates at 6 and 15 to $18^{\circ} \mathrm{C}$. In addition, the variation in crab size within each group increased from instar to instar (Fig. 5).

As in larval biomass, size growth of juveniles follows an exponential pattern:

$$
\ln \mathrm{L}_{\mathrm{c}}=b+m \cdot S_{\mathrm{l}}
$$

where $L_{c}=$ length of carapace $(\mathrm{mm})$; other symbols are the same as in larval growth (see above). These regression curves are shown for 2 groups (Fig. 6) revealing particularly high $\left(9^{\circ} \mathrm{C}\right)$ and low $\left(6^{\circ} \mathrm{C}\right)$ growth rates, the latter extrapolated beyond the last instar surviving in 


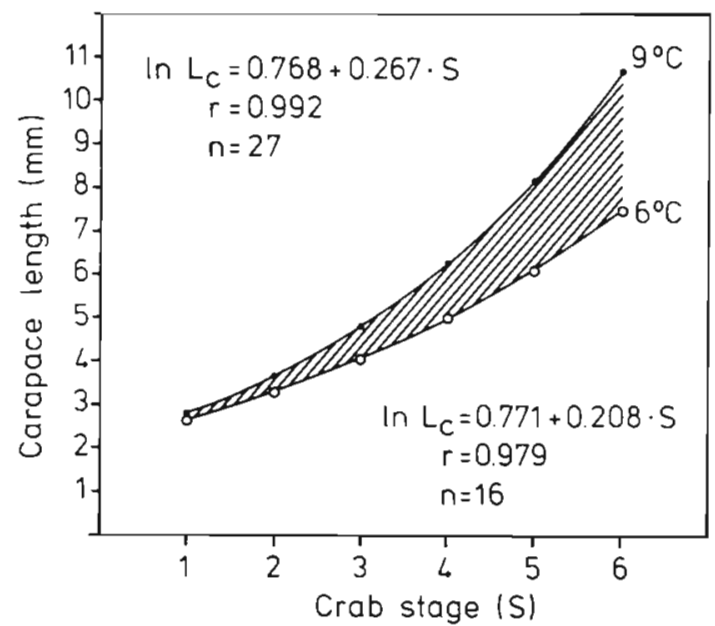

Fig. 6. Hyas coarctatus. Exponential growth of carapace length $\left(L_{c}\right)$ in relation to instar number (crab stage, $S$ ), at 2 different temperatures (fitted curves). Shaded area: range considered characteristic of juvenile growth in $H$. coarctatus. n, r: see Fig. 2

the experiment. The shaded area between these curves indicates the range considered 'characteristic' for Hyas coarctatus. The lower two-thirds of this area are identical with the 'characteristic' range observed in $H$. araneus, and the upper curve in Fig. 6 (calculated from mean values found at $9^{\circ} \mathrm{C}$ ) is very close to the maximum figures reported for $H$. araneus (Kunisch and Anger, 1984).

Since all crabs were reared individually, the construction of a Hiatt growth diagram (Hiatt, 1948) was possible: when carapace length in Stage $S$ (premoult) is plotted against that in Stage $\mathrm{S}+1$ (postmoult), a linear function is obtained (Fig. 7).

\section{DISCUSSION}

\section{Temperature and development}

Like Hyas araneus, $H$. coarctatus is found mainly in boreal and subarctic waters (Christiansen, 1969, 1973, 1982). This geographic distribution is reflected by the lower mortality of larvae and juveniles in relatively cold water (Fig. 1). Very low temperatures, however, are better tolerated by $H$. araneus (Anger, 1983) which in nature also penetrates into colder water than $H$. coarctatus (Christiansen, 1982). This slight difference in distribution, $H$. coarctatus being a more boreal and $H$. araneus a more subarctic species, is reflected not only in mortality patterns, but also in development rate at different temperatures: both species have similar durations of larval development at high temperatures, but $H$. coarctatus develops considerably more slowly in cold water. This fact causes steeper slopes $(\mathrm{m})$ in regression curves calculated for this species (Table 2).

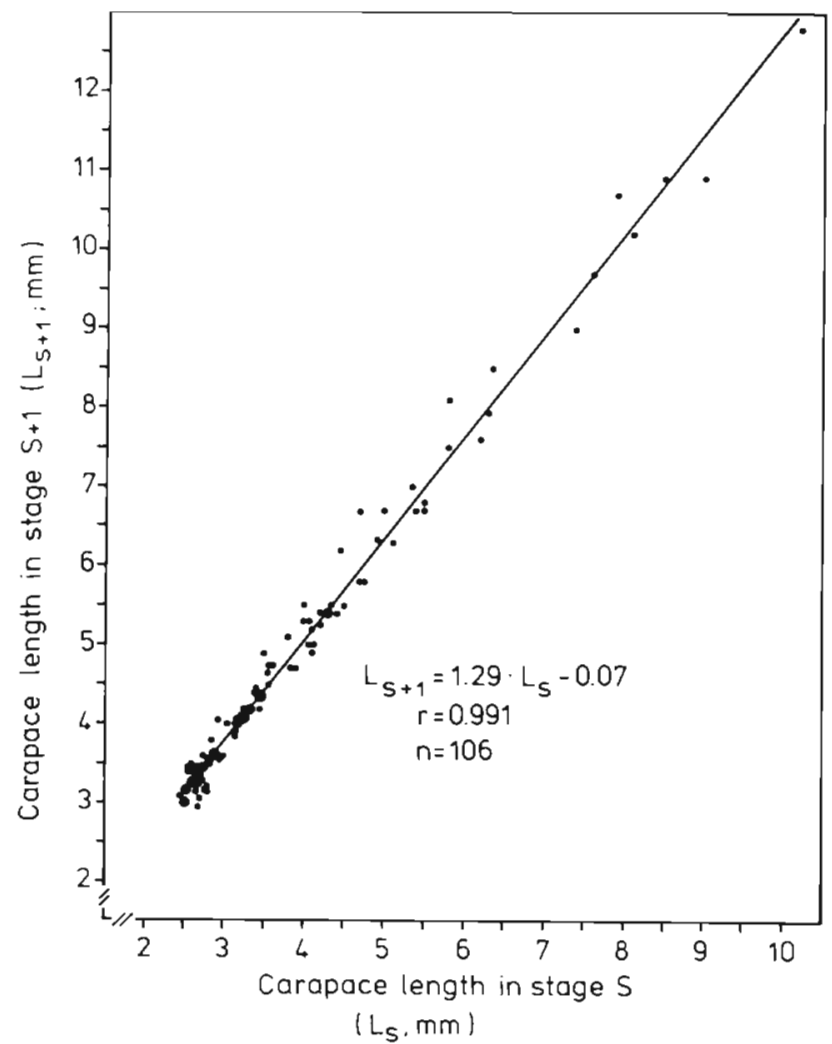

Fig. 7. Hyas coarctatus. Hiatt diagram of juvenile growth. n, r: see Fig. 2

The regression coefficient $(m$ ) of the linearized equation describing development duration in relation to temperature is identical with Bělehrádek's temperature coefficient (Bělehrádek, 1926, 1957) if the difference between physical and biological zero is neglected (Kurata, 1962; Wear, 1974); $m$ appears to increase with decreasing latitude of geographic distribution. This suggestion is supported not only by comparison between Hyas spp. (Table 2) but also by $m$ values observed in larval development of other crab species: in Carcinus maenas (distribution mainly boreal and subtropical; Christiansen, 1969), Dawirs (1982) found coefficients between 1.44 and 1.79. In Rhithropanopeus harrisii (origin: subtropical) Anger et al. (1981) found zoeal development rates from which $m$ values between 1.64 and 2.30 can be calculated. The intercept (a) of the linearized equation, i.e. the theoretical duration of development at $1{ }^{\circ} \mathrm{C}$, also increases with decreasing latitute.

The temperature coefficient $(m)$ decreases during development of crustaceans (Kurata, 1962). There is also such a tendency in Hyas coarctatus, in particular after metamorphosis (Fig. 3). In larval $H$. araneus and $H$. coarctatus, however, $m$ was highest in the second zoeal stage and lowest in the megalopa (Table 2).

Ovigerous females of Hyas coarctatus were found near Helgoland throughout the year (see also Hartnoll, 
1963; Ingle, 1980), and larvae hatched in the laboratory in all seasons. After hatching of the larvae, most females (held without males) laid new eggs which were fertilized with sperm stored in the receptacula seminis. This was observed subsequently up to 3 times during 1 yr, without mating taking place. No signs of reduced viability could be observed in larvae subsequently produced from a single mating. The same phenomenon was investigated by Morgan et al. (1983) in Rhithropanoeus harrisii.

From this observation it might be concluded that Hyas coarctatus can release larvae also in the field throughout the year, with multiple spawning taking place in each female. However, the planktologic literature indicates that larvae only occur in the field in late winter and spring (Ingle, 1980). In addition, Hartnoll (1963) only found eyed embryos between January and April. He suggested that egg-laying takes place from April to August, and hatching of the larvae in the following March and April.

If hatching in Hyas coarctatus is assumed to occur from January to May, metamorphosis to the first crab stage should occur between late May and late June (Fig. 4), i.e. approximately contemporaneously with $H$. araneus (Anger, 1983). This prediction agrees well with the carapace sizes (2.8 to $4.1 \mathrm{~mm}$ ) observed by Hartnoll (1963) in June in $H$. coarctatus. In August the juveniles of this year class should have reached the third and fourth crab stages (ca. 3.6 to $7.4 \mathrm{~mm}$; Fig. 5). Hartnoll (1963) reported that the carapace lengths of a field population were between 4.9 and $8.4 \mathrm{~mm}$ during this month.

Juvenile development may be extrapolated beyond the range shown in Fig. 4. Due both to increasing body size and lower temperatures, the young crabs probably develop at a far lower rate in autumn through spring compared to the first summer (Kurata, 1962; Hartnoll, 1963). They should, however, be able to reach their final size (post-puberty) by their second summer (ca. $1.5 \mathrm{Yr}$ after hatching). This is suggested by intermoult duration (Fig. 3), increase in size with each moult (Fig. 5 and 6), and observations by Hartnoll (1963). He observed that the moult of puberty in Hyas coarctatus can occur over a wide range of carapace lengths (ca. 10 to possibly $40 \mathrm{~mm}$ ). In the second summer he found carapace lengths of 9 to $20 \mathrm{~mm}$. Thus, the largest individuals at least should reach sexual maturity by their second year of life, and 2 yr after hatching their own first offspring should hatch.

\section{Larval and juvenile growth}

The elemental composition ( $\mathrm{C}, \mathrm{N}, \mathrm{H}$ ) and energy content of larval and juvenile Hyas coarctatus is simi- lar to that found in $H$. araneus (Anger and Dawirs, 1982; Anger et al., 1983; Anger, 1984b) and in other decapod larvae (Dawirs, 1980, 1983). Further studies are necessary to show to what degree growth patterns within single instars are similar in different species. Growth from instar to instar is an exponential function of the instar number (Table 4; Fig. 6). This relation has been called 'Dyar's' rule or 'Brook's' law (for review of concepts see Kurata, 1962). It must be stressed, however, that this rule has exceptions (Kurata, 1962), and that growth within single instars of crab larvae has to be interpolated with another model (Anger and Dawirs, 1982; Dawirs, 1983). If comparable periods of different instars are considered (e.g. only early postmoult), the fit of observed and predicted values is good (Anger, 1984b)

The fit becomes much worse, if the biomass data of a freshly metamorphosed crab (Table 3) are included in the regression. Since only a single analysis of a juvenile was made, these results must be treated with caution. The fact that they are well below the figures predicted from larval growth (Table 4) may be caused by an atypically small crab, or by a deviating, bellshaped growth pattern in the megalopa as observed in Hyas araneus (Anger and Dawirs, 1982; Anger et al., 1983), and by high exuvial loss at the metamorphic moult (Anger, 1984b).

Another useful model of arthropod growth was proposed by Hiatt (1948). Linear dimensions of body size as well as weight in premoult Stage $S$ can be plotted against figures in postmoult $(S+1)$, and a linear regression is always obtained (see the extensive review by Kurata, 1962). Inflexion points may be found at metamorphosis and at the moult of puberty. In juvenile growth of Hyas coarctatus no such inflection point was observed (Fig. 7), because crab size was only measured before the moult of puberty, which in this species, is probably the final moult (Hartnoll, 1963). During this phase of the life cycle the characteristic slope of the Hiatt line was 1.29 , which clearly indicates a progressive type of growth (Kurata, 1962).

Comparing larval and postlarval growth of Hyas coarctatus with that in $H$. araneus, the following problem arises: Adult $H$. coarctatus are much smaller than adult $H$. araneus (e.g. Hartnoll, 1963; Christiansen, 1969; Ingle, 1980). A similar difference is evident in freshly hatched larvae (Christiansen, 1973). However, carapace lengths after metamorphosis (in crab I instar) are practically equal in both species (Christiansen, 1973; cf. also Fig. 5 of this paper and Fig. 5 in Kunisch and Anger, 1984). The latter comparison also indicates that the carapace of the later стаb stages is often longer in $H$. coarctatus than in $H$. araneus. Two conclusions can be drawn from these observations: (1) Larval growth (accumulation of biomass) rate from hatching 
to metamorphosis must be considerably higher in $H$. coarctatus than in $H$. araneus. This has already been confirmed by the present study (Table 4). (2) The obviously different final size in these 2 species can only be explained by different total numbers of moults during postlarval growth. If the maximum final carapace length in $H$. coarctatus and $H$. araneus are assumed to be ca. 4 and $7 \mathrm{~cm}$, respectively, it is evident from the equations in Fig. 6 that in order to reach the maximum size, ca. 11 to 14 moults are necessary in $H$. coarctatus, and 13 to 17 in $H$. araneus. As the adult size in the former species appears much more variable than in the latter (Hartnoll, 1963), it is likely that many $H$. coarctatus moult less than 10 times during their postlarval life. The present results (Fig. 6) suggest that as few as 5 postlarval moults may be sufficient to reach maturity and final body size in this spider crab.

Acknowledgements. I am grateful to Miss B. Lämmel and Miss F. Schorn for technical assistance, and to my wife, V. Anger, for helping in a series of experiments. Mr. M. Janke and Dr. E. Wahl provided Artemia nauplii. My sincere thanks are also due to Dr. I. Davison for thoroughly correcting the manuscript.

\section{LITERATURE CITED}

Anger, K., Dawirs, R. R. (1981). Influence of starvation on the larval development of Hyas araneus (Decapoda, Majidae). Helgoländer Meresunters. 34: 287-311

Anger, K., Dawirs, R. R., Anger, V., Goy, J. W., Costlow, J. D. (1981). Starvation resistance in first stage zoeae of brachyuran crabs in relation to temperature. J. Crust. Biol. 1: 518-525

Anger, K., Dawirs, R. R. (1982). Elemental composition (C, N, $\mathrm{H})$ and energy in growing and starving larvae of Hyas araneus (Decapoda, Majidae). Fish. Bull. U.S. 80: 419-433

Anger, K. (1983). Temperature and the larval development of Hyas araneus L. (Decapoda: Majidae); extrapolation of laboratory data to field conditions. J. exp. mar. Biol. Ecol. 69: 203-215

Anger, K., Laasch, N., Püschel, C., Schorn, F. (1983). Changes in biomass and chemical composition of spider crab (Hyas araneus) larvae reared in the laboratory. Mar. Ecol. Prog. Ser. 12: 91-101

Anger, K. (1984a). Influence of starvation on moult cycle and morphogenesis of Hyas araneus larvae (Decapoda, Majidae). Helgoländer Meeresunters. 37: 21-33
Anger, K. (1984b). Gain and loss of particulate organic and inorganic matter in larval and juvenile spider crabs (Hyas araneus) during growth and exuviation. Helgoländer Meeresunters. 37 (in press)

Bělehrádek, J. (1926). Influence of temperature on biological processes. Nature, Lond. 118: 117

Bèlehrádek, J. (1957). Physiological aspects of heat and cold A. Rev. Physiol. 19: 59-82

Christiansen, M. E. (1969). Crustacea Decapoda Brachyura. Marine invertebrates of Scandinavia, No. 2 Universitetsforlaget, Oslo, p. 1-143

Christiansen, M. E. (1973). The complete larval development of Hyas araneus (Linnaeus) and Hyas coarctatus (Decapoda, Brachyura, Majidae) reared in the laboratory. Norw. J. Zool. 21: 63-89

Christiansen, M. E. (1982). A review of the distribution of Crustacea Decapoda Brachyura in the Northeast Atlantic. Quad. Lab. Tecnol. Pesca 3: 347-354

Dawirs, R. R. (1980). Elemental composition (C, N, H) in larval and crab-1 stages of Pagurus bernhardus (Decapoda, Paguridae) and Carcinus maenas (Decapoda, Portunidae). Mar. Biol. 57: 17-23

Dawirs, R. R. (1982). Laboruntersuchungen zur larvalen Entwicklung von Carcinus maenas L. (Decapoda, Portunidae) and Pagurus bemhardus L. (Decapoda, Paguridae). Dissertation, Universität Kiel

Dawirs, R. R. (1983). Respiration, energy balance and development during growth and starvation of Carcinus maenas L. larvae (Decapoda, Portunidae). J. exp. mar. Biol. Ecol. 69: 105-128

Hartnoll, R. G. (1963). The biology of Manx spider crabs. Proc. zool. Soc. Lond. 141: 423-496

Hiatt, R. W. (1948). The biology of the lined shore crab, Pachygrapsus crassipes Randall. Pacif. Sci. 2: 135-213

Ingle, R. W. (1980). British crabs. British Museum and Oxford University Press, London, p. 1-222

Kunisch, M., Anger, K. (1984). Variation in the development and growth rates of larval and juvenile spider crabs (Hyas araneus), reared in the laboratory. Mar. Ecol. Prog. Ser. 15: $293-301$

Kurata, H. (1962). Studies on the age and growth of Crustacea. Bull. Hokkaido Reg. Fish. Lab. 24: 1-115

Morgan, S. G., Goy, J. W., Costlow, J. D. (1983). Multiple ovipositions from single mating in the mud crab Rhithropanopeus harrisii. J. Crust. Biol. 3: 542-547

Salonen, K., Sarvala, J., Hakala, I., Viljanen, M.-L. (1976). The relation of energy and organic carbon in aquatic invertebrates. Limnol. Oceanogr. 21: 724-730

Wear, R. (1974). Incubation in British Decapod Crustacea and the effect of temperature on the rate of success of embryonic development. J. mar. biol. Ass. U.K. 54: 745-762

Weigel, H.-P. (1978). Temperature and salinity observations from Helgoland Reede in 1976. Annls biol. Copenh. 33: 35 